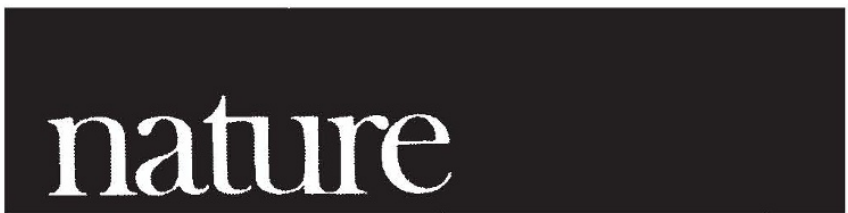

Volume 251

September 20, 1974

\section{Right and wrong ways of expressing concern}

WE publish a letter from Professor F. Janouch on page 181 which together with the appeal from Professor B. Peleska to the World Federation of Scientific Workers (WFSW) (Nature, July 12) makes for most disturbing reading.

For a long time there has been talk of the miseries of some members of the academic profession in Czechoslovakia whose political views did not accord with those of the government. Much of this talk, however, has been coupled with a fear that to name names in the West would simply lead to greater personal distress in the East. And some of the talk has been simply of a subjective nature from visitors- that Prague has become 'the most miserable of capitals' and so on. Fear of naming names is not ill-founded; Professor Peleska has already, it is said, been visited by the police in connection with the letter sent to the WFSW and reprinted with his permission in Nature.

Czechoslovakia then, according to many with whom we have spoken, is at present about as bad a place as any to be an academic devoted to the spirit of liberal enquiry and freedom from repression. What can academics do in a public sense about preventing a breakdown in the standards which they regard as proper for the pursuit of learning? There are, we believe, no essential differences in approach between concern for Czechoslovakia and concern for, say, Chile.

It is easier, of course, to spell out what they shouldn't do.

- They shouldn't assume that an intellectually distinguished body is capable of leading the way diplomatically. The Royal Society in Britain, for instance, has been under much criticism in recent years for its failure to come out publicly on such issues as Soviet treatment of certain scientists. The standard defence is that much good work is done behind the scenes in person-to-person meetings with opposite numbers. This may well be true. but surely the real answer is that a society founded on intellectual distinction should not be asked to do a job requiring a high degree of political acumen.

- They shouldn't expect a politically committed body to deliver the goods. The WFSW has done some excellent bridge-building in the past and may appear, through its clear links with Eastern Europe, to be just the right vehicle for transmitting criticism. But the links with the East have been at the expense of strength in the West and particularly in the United States where an enormous number of scientific workers are and yet where few have even heard of the federation. It is sad that Professor Burhop, president of the federation, should have chosen to respond to the appearance of the Peleska letter by counter-examples of western victimisation, but it shows the weakness of any organisation which as the Roses put it in Science and Society is a victim of cold-war politics and East-West polarisation.

- They shouldn't confine their concern to their own specialisation. An academic community divided into science, sociology and the arts or whatever is weakened, may be to the point of ineffectualness. The world of learning must be indivisible on such matters.

But what positive steps are there to recommend if so often academics have used the wrong channels for their protest? Two seem to be under-explored and worthy of more attention - the approach to politicians and the use of the press.

The elected politician with either his access to or his desire to pose problems for, a government has been underestimated as a means of applying pressure in shaping foreign policy. And the ability of foreign policy to include specific references to the problems of oppressed groups has been inadequately used by academicsalthough a start has recently been made in the inclusion of concern for Soviet Jews in US foreign policy. If a hundred professors in any one country took individual initiatives to harangue their representatives on a matter so obviously not involving self-interest, could that country's foreign policy remain unaltered?

If approaches to politicians might help on a national front, approaches to the journals could rapidly move information around the world in order to create the necessary international climate. Who can doubt that wide publicity of the preposterous behaviour of the Soviet authorities in excising names that displease them from published papers serves a valuable purpose. And the scientist in particular, wedded to the importance of documentary evidence is at once more able to appreciate hard fact and more likely to be able to supply it. It is all-but-impossible for an editor to resist a welldocumented story.

\section{A hundred years ago}

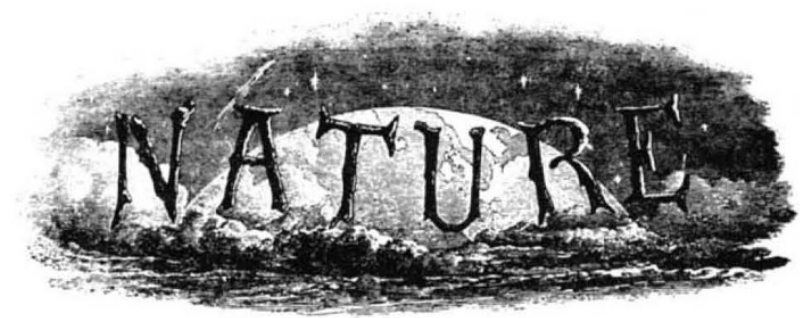

THE will of the late Girolamo Ponti, of Milan, which has just been published in the London Gazette by order of Lord Derby, is likely to give rise to some trouble before it can be carried into effect. The testator has bequealhed a considerable portion of his property to the "Academies of Science of London, Paris, and Vienna," to be divided among them in equal proportions, for the purpose in each case of founding, with the proceeds resulting from investment, two competitions yearly on the subjects of Mechanics, Agriculture, Physics and Chemistry, Travels by Sea and Land, and Literature. The committees to be appointed by the societies are instructed to give preference to those competitors who will have advanced any of the subjects mentioned by original dis. covery. The relatives of Signor Ponti are to dispute the will, and those London societies that think they have claims upon the legacy are urged to bring ihem furward at once. There can be no doubt which societies are meant in the case of Paris and Vienna ; and at first sight there appears to be little doubt as to what body the title of "Academy of Scierce of London" would most appropriately apply.

From Nature, 10, 427, Sept. 24, 1874. 